\title{
The First report of Nigrospora sphaerica Associated with Heliocarpus americanus Seeds in Brazil
}

\author{
Caliandra Bernardi ${ }^{1}$ \\ Maristela dos Santos Rey ${ }^{1}$ (1) \\ Cleverson Busso ${ }^{2}$ \\ Regis Callegaro Borin ${ }^{1}$ \\ Sérgio Miguel Mazaro ${ }^{1}$ \\ Roberto Sadao Sinabucro Saburo ${ }^{1}$
}

\begin{abstract}
Heliocarpus americanus is a fast-growing native tree, excellent for recovering degraded areas and its wood can be used as firewood or in the production of charcoal. For its use it is necessary identify the fungus will cause diseases. This work aimed to make the first report of the occurrence of the fungus Nigrospora sphaerica in seeds of $\mathrm{H}$. americanus in Brazil. The fungus was detected in a batch of seeds collected from the native species. The fungus were analyzed by the Blotter test. Then, the fungus was isolated from the seeds and it characterized by morphology of colony and conidia and, molecular tests, what confirmed the identity of the pathogen. To conclude the study, the Koch's postulates test was performed, where it was observed its transmission of seeds to H. americanus seedlings, elucidating the fungal damage in the seeds and later seedlings of this species.
\end{abstract}

Keyworks: seeds forest, seeds phatolology, forest physiology

Heliocarpus americanus $\mathrm{L}$. is a dioecious native plant that is considered an excellent species for recovering degraded areas because of its rapid growth and economic value in producing wood that can be used as firewood and for charcoal production (Lorenzi, 1992). Thus, this species is a good option for cultivation. To produce healthy and good quality seedlings of this species, seeds with good physiological and sanitary properties should be used. Phytopathogenic fungi are the primary cause of diseases in plant species in forests and nurseries, and many of these fungi remain unidentified, making them difficult to control. To our knowledge, this is the first study reporting the occurrence of the fungus Nigrospora sphaerica in seeds of $H$. americanus in Brazil. In March 2017, seeds were collected directly from the native trees in

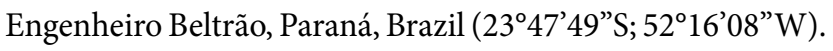
Sanitary quality surveys of the seeds (Silva et al., 2016) revealed that $40 \%$ of the samples had a fungal infection (Figure 1A). This incidence is significant given the risk of transporting phytopathogens associated with the seeds, which represents a mechanism for the spread of pathogens both locally and to new areas. The infected seeds were surface disinfected in $0.5 \% \mathrm{NaClO}$ solution for 1 minute and then washed three times in sterile water. Subsequently, the seeds were placed on potato dextrose agar (PDA) plates and incubated at $24 \pm$ $1^{\circ} \mathrm{C}$ with a photoperiod of 12 hours. The fungi were recovered on the $7^{\text {th }}$ day of incubation. The fungal colonies exhibited filamentous black coloration, a flat raised surface, and filiform borders (Figure 1B). After 10 days of mycelial growth, black, spherical, and unicellular conidia with an average diameter of $18.7 \mu \mathrm{m}$ (range, 15.5-22 $\mu \mathrm{m}$ ) were identified under an optical microscope (Figure 1C). The conidia were present on the hyaline vesicles located at the tip of the short and sparsely branched conidiophores similar to those described by Han et al. (2019). Based on these morphological characteristics, we identified the colonies as N. sphaerica (Sacc.) E.W. Mason. For molecular identification, we extracted fungal DNA directly

${ }^{1}$ Universidade Tecnológica Federal do Paraná (UTFP), Agronomia, Dois Vizinhos, PR, Brasil

${ }^{2}$ Universidade Tecnológica Federal do Paraná (UTFP), Agronomia, Toledo, PR, Brasil 
from the pathogen isolate using the CTAB method (Lee and Taylor, 1990). The internal transcribed spacer region (ITS) of ribosomal DNA was sequenced using the universal primers ITS1/ITS4 (Wang et al., 2017). We deposited a sequence of approximately $500 \mathrm{bp}$ of the ITS1 and ITS4 regions in GenBank (MG897813 and MG897814, respectively). BLAST analysis revealed $99 \%$ similarity between these sequences and those of N. sphaerica (GenBank accession numbers KM921666.1 and KY555021.1). Nigrospora species have commonly been identified as pathogens of many important economic crops, fruits, and ornamental species (Wang et al., 2017). To validate Koch's postulates, we artificially inoculated 200 healthy $H$. americanus seeds and left them in direct contact with the mycelia of fungi grown in a PDA medium for a 72-hour incubation period at $24 \pm 1{ }^{\circ} \mathrm{C}$ with a 12-hour photoperiod. We placed 200 seeds in PDA medium only to serve as a negative control. After inoculation, the seeds were sown and allowed to germinate in a commercial substrate. It was observed that the fungus inhibited germination in $50 \%$ of the seeds. The seeds that did germinate produced wilted seedlings with initial spots of light brown color that subsequently turned dark brown (Figure 1D). N. sphaerica has been reported to produce leaf spots in other species and to reduce production (Han et al., 2019; Pan et al., 2018, Cui et al., 2018). The seeds that were not contaminated with the fungus achieved $100 \%$ germination and remained asymptomatic. We re-isolated the fungus from the symptomatic seedlings and identified it morphologically, thus fulfilling Koch's postulates. A repetition of the experiment produced identical results. This is the first report of N. sphaerica causing wilting and staining in seedlings and reducing germination (by 50\%) of H. americanus seeds in Brazil.

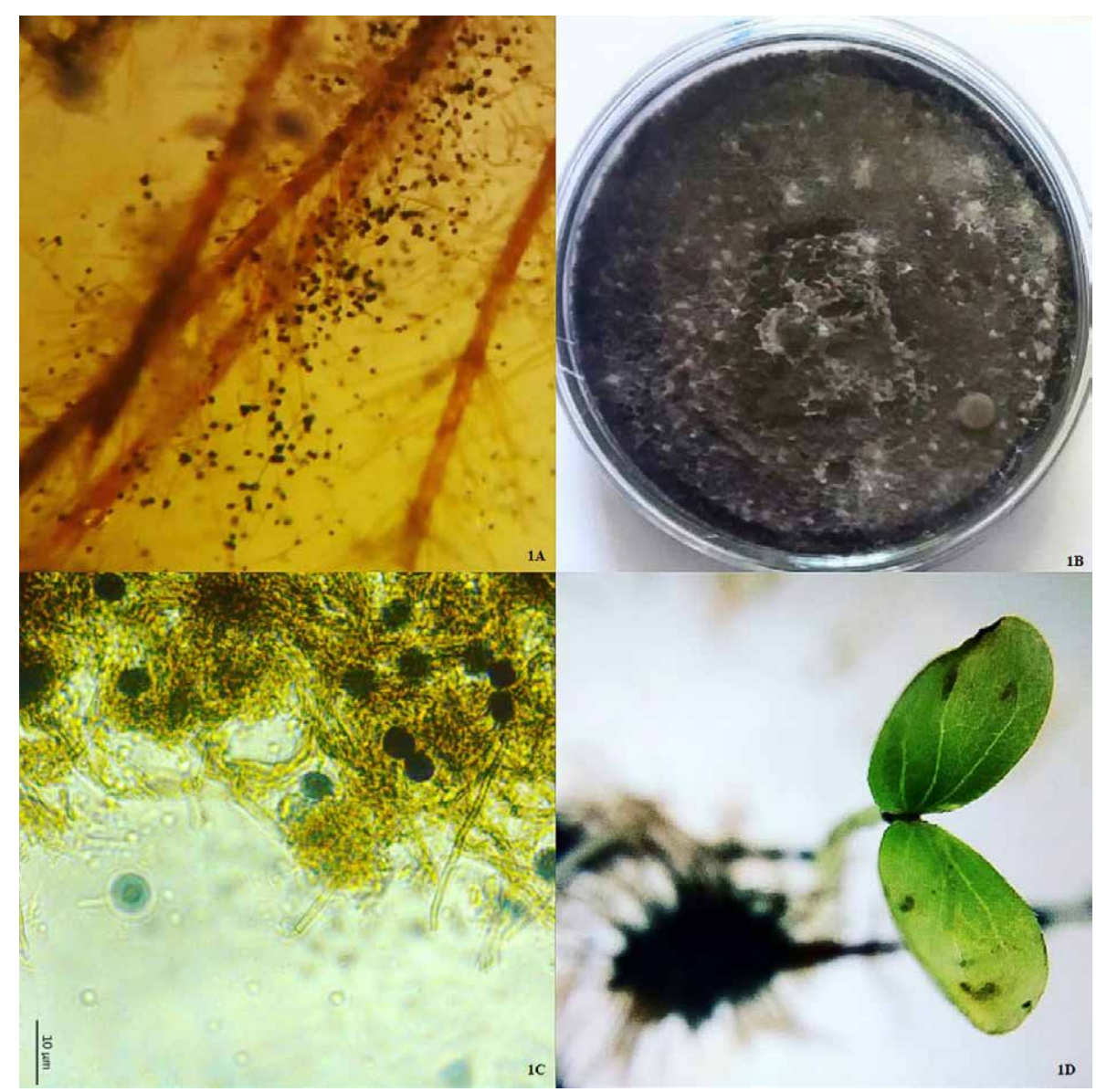

Figura 1. Occurrence of Nigrospora sphaerica in Heliocarpus americanus. 1A. Conidia and mycelium of the fungus on non-germinated seeds of H. americanos. $1 \mathrm{~B}$ Colony of N. sphaerica grown in BDA medium. 1C. Conidia of N. sphaerica seen in optical microscope in increase of 40x. 1D. Necrotic spots caused by Nigrospora sphaerica on Heliocarpus americanus. 


\section{SUBMISSION STATUS}

Received: 14 November. 2019

Accepted: 13 October. 2020

Associate editor: Natane Miranda (D)

\section{CORRESPONDENCE TO}

\section{Maristela dos Santos Rey}

Universidade Tecnológica Federal do Paraná, Estrada para Boa Esperança, Km 04, CEP 85660-000, Dois Vizinhos, PR, Brasil e-mail: maristelarey@utfpr.edu.br

\section{REFERENCES}

Cui, Y. P. Wu, B., Peng, A. T. Li, Z. L., Lin, J. F., and Song, X. B. First Report of Nigrospora Leaf Blight on Sugarcane Caused by Nigrospora sphaerica in China. Plant Disease, 2018, 103-4.
Han, Y. Z., Fan, Z. W.; Wu, C. F., Li, M. Y., Zhou, D. D. First Report of Nigrospora Leaf Blight on Elephant Grass Caused by Nigrospora sphaerica in China. Plant Disease, 2019, 103:10.

Lee, S. B. and Taylor, J. W. PCR Protocols: A Guide to Methods and Applications. Academic Press: San Diego; 1990.

Lorenzi, H. Árvores Brasileiras: Manual de identificação e cultivo de plantas arbóreas nativas do Brasil. Editora Plantarum: São Paulo; 1992.

Silva, F. J. A, Maich, S. L. P, Meneses, P. R, First Report on Exserohilum rostratum Pathogenicity Causing Brown Spot to Rice in Brazil. Plant Disease, 2016, 100:2531.

Pan, L. Li, Liu, H., Li, Y. F., Zhang, D. W., Deng, Q. L., Chen, M. Y., and Zhong, C. H. First Report of Nigrospora sphaerica Causing Kiwifruit Postharvest Rot Disease in China. Plant Disease, 2018, 102-8.

Wang, M.; Liu, F.; Crous, P.W.; Cai, L. Phylogenetic reassessment of Nigrospora: ubiquitous endophytes, plant and human pathogens. Persoonia - Molecular Phylogeny and Evolution of Fungi, 2017, 39:25, 118-142. 